\title{
ANALISIS REAKSI PASAR TERHADAP STOCK SPLIT PADA PERUSAHAAN BERTUMBUH DAN TIDAK BERTUMBUH
}

\author{
Melati \\ Andini Nurwulandari \\ Email: elhusnamelati@gmail.com, andin_manajemen@yahoo.com \\ Program Studi Manajemen Fakultas Ekonomi \\ Universitas Nasional
}

\begin{abstract}
ABSTRAK
Penelitian ini bertujuan untuk menguji dan menganalisis adanya peningkatan harga, volume perdagangan dan abnormal return saham sebelum dan sesudah stock split pada perusahaan bertumbuh dan tidak bertumbuh, serta menguji dan menganalisis adanya harga, volume perdagangan dan abnormal return saham sesudah stock split pada perusahaan bertumbuh yang lebih besar daripada perusahaan tidak bertumbuh. Populasi yang digunakan dalam penelitian ini adalah perusahaan yang terdaftar di Bursa Efek Indonesia dan melakukan stock split berjenis split up pada periode 2011-2015. Dengan menggunakan metode purposive sampling, sampel penelitian terdiri dari 45 perusahaan yang diklasifikasikan ke dalam 36 perusahaan bertumbuh dan sembilan perusahaan tidak bertumbuh. Dengan menggunakan uji beda dua rata-rata, penelitian ini menemukan bahwa terdapat peningkatan harga dan abnormal return saham yang signifikan sebelum dan sesudah stock split pada perusahaan bertumbuh, tidak terdapat peningkatan volume perdagangan saham yang signifikan sebelum dan sesudah stock split pada perusahaan bertumbuh, tidak terdapat peningkatan harga, volume perdagangan dan abnormal return saham yang signifikan sebelum dan sesudah stock split pada perusahaan tidak bertumbuh, terdapat harga, volume perdagangan dan abnormal return saham sesudah stock split pada perusahaan bertumbuh yang lebih besar daripada perusahaan tidak bertumbuh.
\end{abstract}

Kata kunci: Stock split, split up, harga saham, volume perdagangan saham, abnormal return saham, perusahaan bertumbuh, perusahaan tidak bertumbuh, uji beda dua ratarata

This study aims to test and analyze the existence of increases in stock price, trading volume and abnormal return before and after stock split on grow and non grow companies, and to test and analyze the existences of stock price, trading volume and abnornal return after stock split on grow companies that higher than non grow companies. Population that used in this study was companies that listed in Indonesia Stock Exchange and did stock split with split up type in 2011-2015 period. By used purposive sampling method, samples of study contained of 45 companies that classified into 36 grow companies and nine non grow companies. By used the difference of two average test, this study found that there are significant increases in stock price and abnormal return before and after stock split on grow companies, there are no significant increases in stock trading volume before and after stock split on grow companies, there are no significant increases in stock price, trading volume and abnormal return before and after stock split on non grow companies, and there are stock price, trading volume and abnormal return after stock split on grow companies that higher than non grow companies.

Keywords: Stock split, split up, stock price, stock trading volume, stock abnormal return, grow companies, non grow companies, difference of two average test 


\section{PENDAHULUAN}

Pasar modal adalah suatu sistem keuangan yang terorganisasi, termasuk di dalamnya adalah bank-bank komersial dan semua lembaga perantara di bidang keuangan, serta keseluruhan surat-surat berharga yang beredar (Kep. Menkeu RI Nomor 1548/KMK.013/1990).

Investasi di pasar modal menawarkan tingkat pengembalian (return) yang lebih tinggi daripada investasi aset riil dan investasi di pasar uang. Akan tetapi, investasi di pasar modal juga mengandung unsur ketidakpastian yang lebih tinggi daripada investasi aset riil dan investasi di pasar uang. Semakin tinggi tingkat pengembalian (return) yang diharapkan, maka semakin tinggi pula risiko yang dihadapi. Investor dapat mengurangi risiko tersebut dengan cara mengumpulkan informasi yang lengkap mengenai kondisi pasar modal.

Salah satu informasi yang perlu diperhatikan oleh investor adalah informasi mengenai corporate action yang dilakukan oleh perusahaan emiten yang bersangkutan. Salah satu bentuk corporate action yang dapat dilakukan oleh perusahaan adalah stock split. Menurut Brigham dan Gapenski (1994) dalam Astuti (2015), pemecahan saham (stock split) adalah suatu aksi yang dilakukan perusahaan yang go public untuk menaikkan jumlah saham yang beredar.

Pemecahan saham (stock split) merupakan perubahan yang bersifat kosmetik karena tidak berpengaruh terhadap arus kas perusahaan dan proporsi kepemilikan investor. Menurut Marwata (2000) dalam Sakti dan Rini (2013), stock split akan menimbulkan efek fatamorgana bagi investor, yaitu investor merasa seolah-olah menjadi lebih makmur karena memegang saham dalam jumlah yang lebih banyak dari jumlah saham awal yang dimilikinya. Akan tetapi, harga pasar saham tersebut akan mengalami penurunan sesuai dengan faktor split sehingga total nilai saham yang dipegang oleh investor akan tetap sama. Oleh karena itu, stock split merupakan tindakan perusahaan yang tidak memiliki nilai ekonomi (Van Horne dan Wachowicz, 2012). Akan tetapi, pada kenyataannya terdapat beberapa penelitian yang menunjukkan bahwa stock split memiliki dampak yang positif terhadap pasar. Reaksi yang diberikan pasar terhadap stock split dapat diukur dengan perubahan harga saham, volume perdagangan saham dan abnormal return saham.

Berikut ini merupakan grafik rata-rata return saham harian perusahaan di Bursa Efek Indonesia yang melakukan stock split berjenis split up pada periode 2011-2015. 


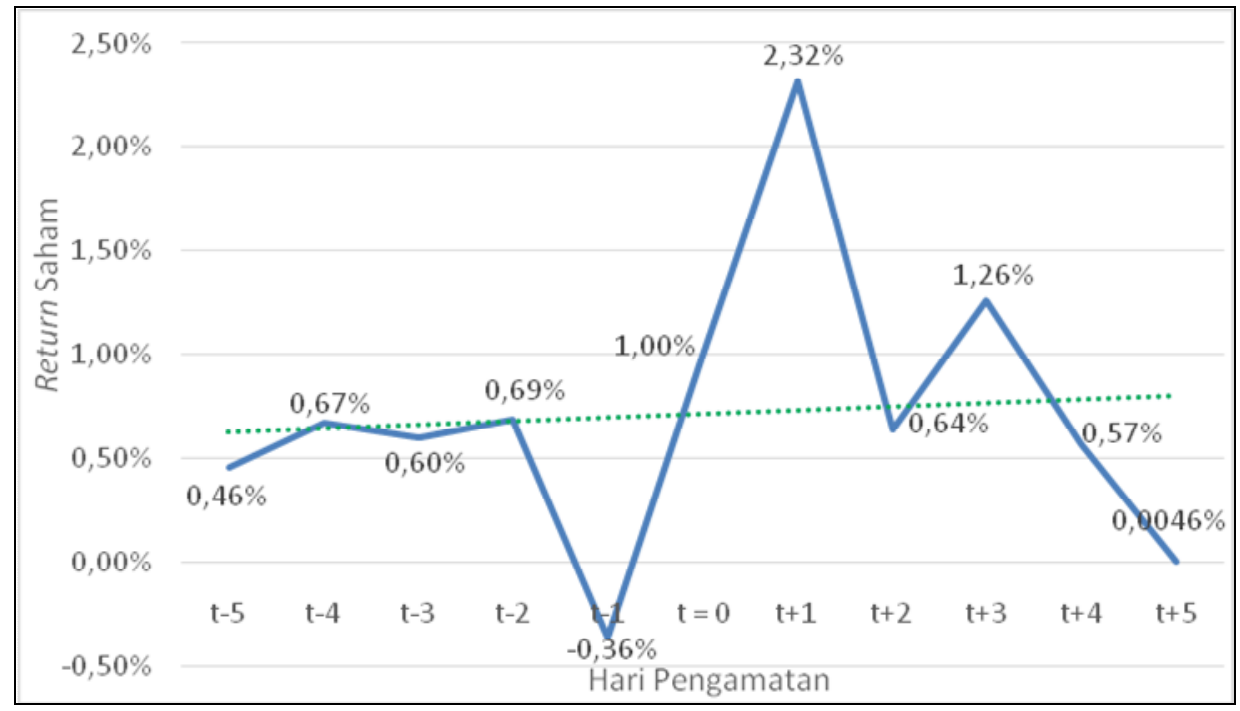

(Sumber: KSEI dan Yahoo Finance, 2016)

Gambar 1. Rata-Rata Return Saham Harian

Sebelum dan Sesudah Stock Split

Berdasarkan data di atas, return saham perusahaan yang melakukan stock split cenderung mengalami kenaikan sebelum dan sesudah stock split. Meskipun return saham perusahaan menyentuh angka negatif pada satu hari sebelum stock split, return kembali naik pada cum date dan satu hari sesudahnya. Rata-rata return saham selama lima hari sebelum stock split adalah $0,41 \%$, sedangkan rata-rata return saham selama lima hari sesudah stok split mencapai 0,96\%. Artinya, return saham mengalami kenaikan sebesar 0,55\% sesudah stock split. Hal tersebut merupakan bukti empiris bahwa stock split dapat mempengaruhi return saham. Fakta ini bertolak belakang dengan beberapa pendapat yang menyatakan bahwa stock split hanya merupakan perubahan yang bersifat kosmetik karena tidak memiliki dampak pada arus kas. Pada kenyataannya, return saham sesudah stock split cenderung mengalami kenaikan. Hal tersebut menunjukkan bahwa harga saham relatif dan nilai saham sesudah stock split juga mengalami kenaikan.

Kenaikan return yang ditunjukkan pada gambar di atas mencerminkan adanya kenaikan closing price harian perusahaan yang bersangkutan. Closing price merupakan harga yang ditentukan oleh permintaan dan penawaran di bursa. Kenaikan closing price tersebut mencerminkan bahwa investor memberikan reaksi yang positif terhadap stock split yang dilakukan oleh perusahaan. Hal ini menentang beberapa penelitian terdahulu yang menyatakan bahwa stock split tidak menimbulkan dampak dan reaksi di pasar.

Berdasarkan perbedaan bukti empiris dan hasil penelitian terdahulu tentang stock split, perlu dilakukan penelitian untuk menguji dan menganalisis adanya reaksi pasar yang 
positif terhadap stock split yang ditunjukkan dengan adanya peningkatan harga saham, volume perdagangan saham dan abnormal return saham sebelum dan sesudah stock split.

Hasil penelitian yang dilakukan oleh Norpratiwi (2007) dalam Ningrum (2011) menunjukkan bahwa rasio Market to Book Value of Equity (MVEBVE) sebagai salah satu proksi Investment Opportunity Set (IOS) berbasis harga memiliki hubungan yang positif dengan abnormal return sesudah pelaporan kondisi keuangan perusahaan. Hal ini didukung oleh penelitian yang dilakukan Ningrum (2011) yang menunjukkan bahwa rasio MVEBVE memiliki pengaruh yang positif dan signifikan terhadap return saham. Semakin tinggi rasio MVEBVE dan tingkat pertumbuhan suatu perusahaan, maka semakin tinggi pula return saham perusahaan tersebut.

Berdasarkan hal tersebut, perlu dilakukan penelitian untuk menguji dan menganalisis adanya abnormal return saham sesudah stock split pada perusahaan bertumbuh (MVEBVE > 1) yang lebih besar daripada perusahaan tidak bertumbuh (MVEBVE $<1$ ). Oleh karena itu, sampel dalam penelitian ini akan dikelompokkan ke dalam perusahaan bertumbuh dan tidak bertumbuh untuk menguji dan menganalisis adanya reaksi pasar yang lebih baik terhadap stock split yang dilakukan oleh perusahaan bertumbuh daripada perusahaan tidak bertumbuh yang ditunjukkan dengan adanya harga saham, volume perdagangan saham dan abnormal return saham sesudah stock split pada perusahaan bertumbuh yang lebih besar daripada perusahaan tidak bertumbuh.

Penelitian ini bertujuan untuk menguji dan menganalisis adanya peningkatan harga saham, volume perdagangan saham dan abnormal return saham sebelum dan sesudah stock split pada perusahaan bertumbuh dan tidak bertumbuh, serta menguji dan menganalisis adanya harga saham, volume perdagangan saham dan abnormal return saham sesudah stock split pada perusahaan bertumbuh yang lebih besar daripada perusahaan tidak bertumbuh.

\section{TINJAUAN PUSTAKA}

\section{Signalling Theory}

Signalling theory menyatakan bahwa suatu kebijakan yang diambil oleh emiten, pemerintah, atau investor pada prinsipnya memberikan sinyal atau pertanda bagi pasar tentang tren atau kecenderungan di masa yang akan datang (Husnan, 2010). Signalling theory menyatakan bahwa stock split merupakan sinyal baik yang diberikan oleh perusahaan kepada publik yang berkaitan dengan prospek perusahaan di masa depan. Perusahaan yang melakukan stock split adalah perusahaan yang memiliki saham dengan harga yang tinggi, sehingga menjadi sinyal bahwa perusahaan memiliki prospek masa depan yang baik. Hal ini 
dikarenakan harga saham yang tinggi mencerminkan bahwa perusahaan memiliki kinerja yang baik (Jogiyanto, 2016).

\section{Trading Range Theory}

Trading range theory menyatakan bahwa harga saham yang terlalu tinggi menyebabkan kurang aktifnya perdagangan saham sehingga mendorong perusahaan untuk melakukan stock split. Fahmi (2012) menyatakan bahwa stock split membuat harga saham tidak terlalu tinggi sehingga mampu dijangkau oleh calon investor kecil. Hal tersebut akan meningkatkan likuiditas saham yang bersangkutan.

\section{Efisiensi Pasar}

Pasar modal yang efisien adalah pasar modal yang harga sekuritasnya telah mencerrminkan semua informasi yang relevan (Husnan, 2010:260). Pasar yang efisien dapat didefinisikan sebagai pasar yang harga sekuritasnya secara penuh mencerminkan semua informasi yang diketahui secara cepat dan akurat (Jones, et al. 2009:353).

\section{Market Overreaction}

Overreaction adalah suatu pergerakan terbalik yang terjadi setelah kenaikan atau penurunan harga saham yang disebabkan oleh tindakan investor yang berlebihan berdasarkan informasi saat ini (Yi, et al., 2016).

Market overreaction merupakan suatu kondisi ketika pasar bereaksi secara berlebihan terhadap suatu informasi. De Bond dan Thaler (1985) dalam Octavio dan Lantara (2014) menyatakan bahwa market overreaction terjadi karena investor mempunyai kecenderungan untuk menilai terlalu tinggi informasi terbaru yang mengubah persepsi dan ekspektasi terhadap perusahaan, sehingga kurang memperhatikan informasi terdahulu.

\section{Market Underreaction}

Market underreaction menyatakan bahwa harga saham terlalu kurang bereaksi terhadap informasi-informasi baru yang diumumkan oleh perusahaan. Harga saham cenderung tetap naik setelah reaksi awal positif. Sebaliknya, harga saham cenderung tetap turun setelah reaksi awal negatif. Pasar modal yang underreaksi biasanya sensitif terhadap beberapa informasi, khususnya tindakan korporat, seperti pembelian kembali saham pasar terbuka dan stock split (Yi, et al., 2016). 


\section{Harga Saham Sebelum dan Sesudah Stock Split}

Sari (2011) menyatakan bahwa stock split dapat menaikkan harga pasar saham. Stock split membuat nilai nominal saham menjadi lebih murah sehingga permintaan terhadap saham meningkat. Hal ini akan meningkatkan likuiditas saham yang lama-kelamaan akan menyebabkan kenaikan harga saham dan minat investor.

Hal ini didukung oleh Fatmawati dan Asri (1999), Wang, et al. (2000), Menendez dan Gomez (2003), dan Leung, et al. (2005) dalam Noerfuad (2015) yang menyatakan bahwa terdapat perbedaan yang signifikan pada harga saham sebelum dan sesudah stock split.

$\mathrm{H}_{1}$ : Terdapat peningkatan harga saham sebelum dan sesudah stock split pada perusahaan bertumbuh.

$\mathrm{H}_{2}$ : Terdapat peningkatan harga saham sebelum dan sesudah stock split pada perusahaan tidak bertumbuh.

\section{Volume Perdagangan Saham Sebelum dan Sesudah Stock Split}

Trading range theory menyatakan bahwa harga saham yang terlalu tinggi menyebabkan kurang aktifnya perdagangan saham sehingga mendorong perusahaan untuk melakukan stock split. Fahmi (2012) menyatakan bahwa stock split membuat harga saham tidak terlalu tinggi sehingga mampu dijangkau oleh calon investor kecil. Hal tersebut akan meningkatkan likuiditas saham perusahaan yang bersangkutan.

Hal tersebut didukung oleh Sadikin (2011) yang menunjukkan bahwa terdapat perbedaan trading volume activity yang signifikan sebelum dan sesudah stock split. Sakti dan Rini (2013) menyatakan bahwa terdapat perbedaan yang signifikan pada volume perdagangan saham sebelum dan sesudah stock split pada perusahaan bertumbuh

$\mathrm{H}_{3}$ : Terdapat peningkatan volume perdagangan saham sebelum dan sesudah stock split pada perusahaan bertumbuh.

$\mathrm{H}_{4}$ : Terdapat peningkatan volume perdagangan saham sebelum dan sesudah stock split pada perusahaan tidak bertumbuh.

\section{Abnormal Return Saham Sebelum dan Sesudah Stock Split}

Stock split membuat nilai nominal saham menjadi lebih murah sehingga permintaan terhadap saham meningkat. Hal ini akan meningkatkan likuiditas saham yang lama-kelamaan akan menyebabkan kenaikan harga saham dan minat investor. Kenaikan harga saham akan 
menyebabkan timbulnya kenaikan return yang menyebabkan munculnya abnormal return yang positif.

Hal ini didukung oleh Meylita dan Yasa (2015) yang menyatakan bahwa terdapat perbedaan abnormal return yang signifikan di sekitar pengumuman stock split.

$\mathrm{H}_{5}$ : Terdapat peningkatan abnormal return saham sebelum dan sesudah stock split pada perusahaan bertumbuh.

$\mathrm{H}_{6}$ : Terdapat peningkatan abnormal return saham sebelum dan sesudah stock split pada perusahaan tidak bertumbuh.

\section{Reaksi Pasar terhadap Stock Split pada Perusahaan Bertumbuh dan Tidak Bertumbuh}

Hasil penelitian yang dilakukan oleh Norpratiwi (2007) dalam Ningrum (2011) menunjukkan bahwa rasio Market to Book Value of Equity (MVEBVE) sebagai salah satu proksi Investment Opportunity Set (IOS) berbasis harga memiliki hubungan yang positif dengan abnormal return sesudah pelaporan kondisi keuangan perusahaan. Hal ini didukung oleh penelitian yang dilakukan Ningrum (2011) yang menunjukkan bahwa rasio MVEBVE memiliki pengaruh yang positif dan signifikan terhadap return saham. Semakin tinggi rasio MVEBVE dan tingkat pertumbuhan suatu perusahaan, maka semakin tinggi pula return saham perusahaan tersebut.

Pengaruh positif dan signifikan MVBVE terhadap return saham menunjukkan bahwa MVBVE juga dapat mempengaruhi harga saham, likuiditas saham dan abnormal return saham secara tidak langsung. Hal tersebut dikarenakan peningkatan return saham disebabkan oleh adanya peningkatan harga saham yang dapat menyebabkan timbulnya peningkatan abnormal return saham. Peningkatan harga saham juga dapat meningkatkan citra perusahaan, sehingga menyebabkan terjadinya peningkatan volume perdagangan saham.

Hal tersebut didukung oleh Dalimunthe, dkk. (2015) yang menyatakan bahwa terdapat perbedaan harga dan volume perdagangan saham yang signifikan antara perusahaan bertumbuh dan tidak bertumbuh sesudah pengumuman stock split

$\mathrm{H}_{7}$ : Harga saham sesudah stock split pada perusahaan bertumbuh lebih besar daripada perusahaan tidak bertumbuh.

$\mathrm{H}_{8}$ : Volume perdagangan saham sesudah stock split pada perusahaan bertumbuh lebih besar daripada perusahaan tidak bertumbuh. 
$\mathrm{H}_{9}$ : Abnormal return saham sesudah stock split pada perusahaan bertumbuh lebih besar daripada perusahaan tidak bertumbuh.

\section{Kerangka Analisis}

Berikut ini merupakan kerangka analisis dalam penelitian ini.

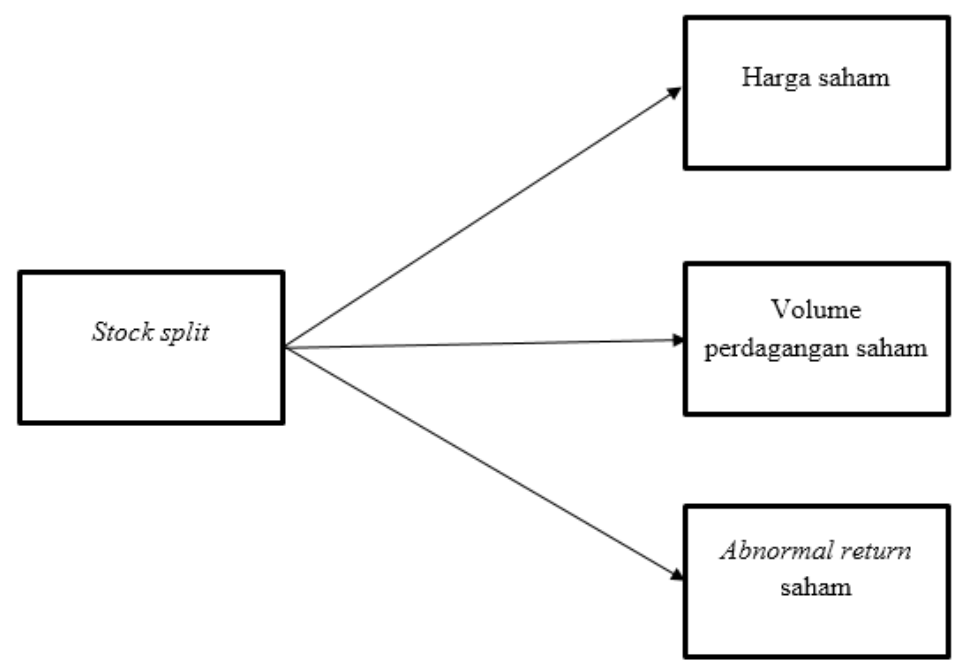

Gambar 2. Kerangka Analisis

\section{METODE PENELITIAN}

\section{Sumber dan Jenis Data}

Data yang digunakan dalam penelitian ini bersumber dari situs resmi Bursa Efek Indonesia (http://www.idx.co.id), Kustodian Sentra Efek Indonesia (http://www.ksei.co.id), dan Yahoo Finance (http://www.finance.yahoo.com). Jenis data yang digunakan dalam penelitian ini adalah data sekunder dan kuantitatif. Data tersebut diamati berdasarkan urutan waktu pada perusahaan yang terdaftar di Bursa Efek Indonesia dan melakukan stock split berjenis split up pada periode 2011-2015 sehingga merupakan data panel atau gabungan antara data time series dan cross section.

\section{Populasi dan Sampel}

Populasi yang digunakan dalam penelitian ini adalah perusahaan-perusahaan yang terdaftar di Bursa Efek Indonesia dan melakukan stock split berjenis split up (pemecahan naik) pada periode 2011-2015. Populasi penelitian terdiri dari 58 perusahaan.

Pengambilan sampel dilakukan menggunakan metode purposive sampling. Kriteria sampel yang digunakan antara lain perusahaan tidak melakukan corporate action lain berupa 
right issue, pembagian saham bonus, dividen tunai, dan dividen saham selama periode pengamatan, serta perusahaan memiliki kelengkapan data laporan keuangan yang disajikan dalam rupiah.

Berdasarkan kriteria tersebut, sampel penelitian terdiri dari 45 perusahaan.Sampel tersebut kemudian dikelompokkan ke dalam perusahaan bertumbuh dan tidak bertumbuh menggunakan salah satu proksi Investment Opportunity Set (IOS) yang paling valid dan konsisten sebagai proksi pertumbuhan menurut Norpratiwi (2007) dalam Ningrum (2011), yaitu rasio Market to Book Value of Equity (MVEBVE). MVEBVE dapat dihitung dengan rumus sebagai berikut.

$$
\text { MVEBVE }=\frac{\text { Jumlah lembar saham beredar } \mathrm{x} \text { harga saham penutupan }}{\text { Total ekuitas }}
$$

Berikut ini merupakan kriteria pengklasifikasian tingkat pertumbuhan perusahaan menggunakan MVEBVE.

a. Jika MVEBVE > 1, maka perusahaan digolongkan menjadi perusahaan bertumbuh.

b. Jika MVEBVE < 1, maka perusahaan digolongkan menjadi perusahaan tidak bertumbuh.

Berdasarkan kriteria tersebut, sampel penelitian terdiri dari 36 perusahaan betumbuh dan sembilan perusahaan tidak bertumbuh. Tingkat pertumbuhan perusahaan diasumsikan konstan selama periode pengamatan.

\section{Definisi Operasional dan Pengukuran Variabel}

\section{Stock Split}

Dalam penelitian ini, yang dimaksud dengan stock split adalah peningkatan jumlah saham beredar dengan mengurangi nilai nominal saham (pemecahan naik/split up).

\section{Harga Saham}

Dalam penelitian ini, yang dimaksud dengan harga saham adalah harga pasar yang tercatat setiap hari pada waktu penutupan dari suatu saham (closing price).

Harga saham relatif sebelum stock split adalah perbandingan harga saham sebelum stock split dengan hasil perbandingan antara nilai nominal saham sebelum stock split dan nilai nominal saham tersebut setelah stock split.

$$
\mathrm{HR}_{\text {sebehmo }}=\frac{\mathrm{P}_{\mathrm{seb}}}{\left(\frac{\mathrm{Nt}}{\mathrm{N}+1}\right)}
$$


Keterangan:

HR = Harga saham relatif sebelum stock split

$\mathrm{P}_{\text {seb }} \quad$ = Harga saham sebelum stock split

$\mathrm{N}_{\mathrm{t}} \quad$ = Nilai nominal saham sebelum stock split

$\mathrm{N}_{\mathrm{t}+1} \quad=$ Nilai nominal saham setelah stock split

\section{Volume Perdagangan Saham}

Dalam penelitian ini, yang dimaksud dengan volume perdagangan saham (trading volume activity) adalah perbandingan antara jumlah saham yang diperdagangkan dan jumlah saham yang beredar.

$$
\text { TVAit }=\frac{\sum \text { saham i yang diperdagangkan pada hari ke-t }}{\sum \text { saham i yang beredar pada hari ke-t }}
$$

\section{Abnormal Return}

Dalam penelitian ini, yang dimaksud dengan abnormal return adalah selisih antara return yang sesungguhnya (actual return) dan return pasar. Return pasar digunakan karena model penghitungan expected return yang digunakan adalah market adjusted model.

$$
\mathrm{AR}_{\mathrm{it}}=\mathrm{R}_{\mathrm{it}}-\mathrm{R}_{\mathrm{mt}}
$$

Keterangan:

$\mathrm{AR}_{\mathrm{it}} \quad=$ Abnormal return saham i pada periode peristiwa ke- $\mathrm{t}$

$\mathrm{R}_{\mathrm{it}} \quad=$ Return realisasi saham i pada periode peristiwa ke- $\mathrm{t}$

$\mathrm{R}_{\mathrm{mt}} \quad=$ Return pasar

Return yang sesungguhnya (actual return) adalah perbandingan antara selisih harga saham periode ke-t dengan periode sebelumnya.

$$
R_{i t}=\frac{P_{i t}-P_{i t-1}}{P_{t t-1}}
$$

Keterangan:

$\mathrm{P}_{\text {it }} \quad=$ Harga saham i pada periode peristiwa ke- $\mathrm{t}$

$\mathrm{P}_{\mathrm{it}-1} \quad=$ Harga saham $\mathrm{i}$ pada periode peristiwa ke $\mathrm{t}-1$

Return pasar merupakan perbandingan antara selisih Indeks Harga Saham Gabungan (IHSG) periode ke-t dengan periode sebelumnya.

$$
\mathbf{R m}=\frac{\text { IHSG }- \text { IHSG } \cdot 1}{\text { IHSG }-1}
$$


Keterangan:

$\mathrm{IHSG}_{\mathrm{t}} \quad=$ Indeks Harga Saham Gabungan pada periode peristiwa ke-t

$\mathrm{IHSG}_{\mathrm{t}-1} \quad=$ Indeks Harga Saham Gabungan pada periode peristiwa ke-t-1

\section{Metode Analisis}

Penelitian ini menggunakan teknik analisis studi peristiwa (event study) untuk menganalisis reaksi pasar terhadap stock split yang diukur dengan harga saham, volume perdagangan saham dan abnormal return saham. Event window atau periode pengamatan yang digunakan dalam penelitian ini adalah periode lima hari sebelum (t-5 sampai dengan t1) peristiwa (pre event window) dan lima hari sesudah $(\mathrm{t}+1$ sampai dengan $\mathrm{t}+5)$ peristiwa (post event period). Periode pengamatan tersebut digunakan karena dianggap sebagai window yang paling tepat dalam menunjukkan sinyal keuntungan dan kenaikan likuiditas saham dalam jangka pendek akibat stock split. Selain itu, periode pengamatanyang terlalu lama dikhawatirkan dapat menyebabkan tercampurnya reaksi pasar terhadap stock split dengan peristiwa lain sehingga dapat mengurangi tingkat akurasi hasil penelitian. Penelitian tentang perubahan harga saham, volume perdagangan saham dan abnormal return akibat stock split yang telah dilakukan oleh Wijanarko (2012) dan Sakti dan Rini (2013) juga menggunakan window 5 hari sebelum dan sesudah peristiwa.

Analisis yang dilakukan dalam penelitian ini terdiri dari uji normalitas, uji homogenitas, dan uji beda dua rata-rata (t-test).

\section{HASIL PENELITIAN DAN PEMBAHASAN}

\section{Hasil Penelitian}

\section{Hasil Uji Normalitas}

Uji normalitas dilakukan untuk mengetahui normalitas sebaran data yang digunakan. Dalam penelitian ini, normalitas data diuji menggunakan Shapiro Wilk Test. Hasil uji normalitas menunjukkan bahwa semua data dalam penelitian ini memiliki $p$-value $>0,05$, sehingga data berdistribusi normal. Berdasarkan hal tersebut, pengujian hipotesis dilakukan menggunakan statistik parametrik, yaitu paired sample t-test dan independent sample t-test.

\section{Hasil Uji Homogenitas}

Uji homogenitas dilakukan untuk mengetahui sama atau tidaknya varians kelompok data yang akan digunakan dalam penelitian. Homogenitas diuji menggunakan Levene's Test. 
Tabel 1. Hasil Uji Homogenitas

\begin{tabular}{|l|c|c|l|}
\hline Variabel & $\boldsymbol{P}$-Value & $\boldsymbol{\alpha}$ & \multicolumn{1}{|c|}{ Keterangan } \\
\hline Harga & 0,000 & 0,05 & Tidak homogen \\
\hline TVA & 0,457 & 0,05 & Homogen \\
\hline AR & 0,283 & 0,05 & Homogen \\
\hline
\end{tabular}

(Sumber: Data diolah, 2016)

Berdasarkan hasil uji homogenitas, hasil independent sample-t test pada harga saham yang digunakan adalah hasil pada lajur equal variances not assumed. Sementara itu, hasil independent sample-t test pada volume perdagangan saham dan abnormal return saham yang digunakan adalah hasil pada lajur equal variances assumed.

\section{Hasil Pengujian Hipotesis}

Berikut ini merupakan tabel yang menunjukkan hasil pengujian hipotesis.

Tabel 2. Hasil Pengujian Hipotesis

\begin{tabular}{|c|r|r|r|r|l|}
\hline Hipotesis & \multicolumn{1}{|c|}{$\begin{array}{c}\text { Mean } \\
\text { Difference }\end{array}$} & \multicolumn{1}{|c|}{$\mathbf{t}$} & $\begin{array}{c}\text { P-Value } \\
\text { (Sig. 2- } \\
\text { tailed })\end{array}$ & $\begin{array}{c}\text { P-Value } \\
\text { (Sig. 1- } \\
\text { tailed })\end{array}$ & \multicolumn{1}{|c|}{ Keterangan } \\
\hline 1 & $-425,79000$ & $-5,550$ & 0,005 & 0,0025 & H0 ditolak dan Ha diterima \\
\hline 2 & $-4,65488$ & $-1,134$ & 0,320 & 0,1600 & H0 diterima \\
\hline 3 & $-0,000108800$ & $-0,414$ & 0,700 & 0,3500 & H0 diterima \\
\hline 4 & 0,000418200 & 1,084 & 0,339 & 0,1695 & H0 diterima \\
\hline 5 & $-0,014306200$ & $-3,274$ & 0,031 & 0,0155 & H0 ditolak dan Ha diterima \\
\hline 6 & 0,011253800 & 0,579 & 0,594 & 0,2970 & H0 diterima \\
\hline 7 & $-3396,99244$ & $-52,883$ & 0,000 & 0,0000 & H0 ditolak dan Ha diterima \\
\hline 8 & $-0,000465800$ & $-2,036$ & 0,076 & 0,0380 & H0 ditolak dan Ha diterima \\
\hline 9 & $-0,020686800$ & $-2,116$ & 0,067 & 0,0335 & H0 ditolak dan Ha diterima \\
\hline
\end{tabular}

(Sumber: Data diolah, 2016)

Berdasarkan tabel di atas, dapat diketahui bahwa terdapat peningkatan harga saham yang signifikan sebelum dan sesudah stock split pada perusahaan bertumbuh, tidak terdapat peningkatan harga saham yang signifikan sebelum dan sesudah stock split pada perusahaan tidak bertumbuh, terdapat harga saham sesudah stock split pada perusahaan bertumbuh yang lebih besar secara signifikan daripada perusahaan tidak bertumbuh, tidak terdapat peningkatan volume perdagangan saham yang signifikan sebelum dan sesudah stock split pada perusahaan bertumbuh, terdapat penurunan volume perdagangan saham sebelum dan sesudah stock split pada perusahaan tidak bertumbuh, terdapat volume perdagangan saham sesudah stock split pada perusahaan bertumbuh yang lebih besar secara signifikan daripada perusahaan tidak bertumbuh, terdapat peningkatan abnormal return saham yang signifikan sebelum dan sesudah stock split pada perusahaan bertumbuh, terdapat penurunan abnormal return saham sebelum dan sesudah stock split pada perusahaan tidak bertumbuh, terdapat 
abnormal return saham sesudah stock split pada perusahaan bertumbuh yang lebih besar secara signifikan daripada perusahaan tidak bertumbuh.

\section{Pembahasan}

\section{Pembahasan Hasil Pengujian Hipotesis 1}

Berdasarkan hasil uji-t tersebut, p-value (one tailed) sebesar 0,0025 lebih kecil daripada tingkat signifikansi $\alpha$ sebesar 0,05, sehingga $\mathrm{H} 0$ ditolak dan Ha diterima. Hasil tersebut menunjukkan bahwa terdapat peningkatan harga saham yang signifikan sebelum dan sesudah stock split pada perusahaan bertumbuh. Besarnya rata-rata peningkatan harga saham harian sebelum dan sesudah stock split pada perusahaan bertumbuh adalah Rp 425,79.

Hasil tersebut sejalan dengan hasil penelitian yang dilakukan oleh Menendez dan Gomez (2003) dan Leung, et al. (2005) dalam Noerfuad (2015) yang menunjukkkan bahwa terdapat perbedaan yang signifikan pada harga saham sebelum dan sesudah stock split. Akan tetapi, penelitian tersebut tidak menjelaskan lebih lanjut bahwa perbedaan tersebut berupa peningkatan harga saham. Penelitian tersebut juga tidak secara khusus menggunakan perusahaan bertumbuh sebagai sampel penelitiannya.

Peningkatan harga saham sebelum dan sesudah stock split pada perusahaan bertumbuh menunjukkan adanya reaksi positif yang diberikan oleh investor terhadap stock split yang dilakukan oleh perusahaan bertumbuh. Nilai nominal saham yang lebih rendah setelah terjadinya stock split pada perusahaan bertumbuh berhasil menarik minat investor untuk membeli saham tersebut. Investor yang semula tidak membeli saham karena tingginya harga saham, dapat menjangkau harga saham sesudah stock split dengan nilai nominal yang lebih rendah. Peningkatan jumlah investor yang melakukan permintaan untuk membeli suatu saham menyebabkan terjadinya peningkatan harga pasar dari saham tersebut. Oleh karena itu, harga saham sesudah stock split mengalami peningkatan dari harga saham relatif sebelum stock split.

Berdasarkan signalling theory, peningkatan harga saham tersebut disebabkan oleh reaksi investor terhadap informasi dan optimisme manajemen perusahaan terhadap prospek perusahaan di masa yang akan datang yang disinyalkan melalui stock split. Semakin tinggi tingkat pertumbuhan suatu perusahaan, maka semakin tinggi pula return dan harapan investor terhadap return dan prospek dari perusahaan tersebut di masa yang akan datang. Oleh karena itu, investor tertarik membeli saham sesudah stock split pada perusahaan bertumbuh.

Peningkatan harga saham sebelum dan sesudah stock split pada perusahaan bertumbuh menunjukkan bahwa harga saham di Bursa Efek Indonesia mencerminkan secara cepat dan 
akurat semua informasi yang dipublikasikan, termasuk informasi stock splitdilakukan oleh perusahaan bertumbuh. Hal ini menunjukkan bahwa tingkat efisiensi Bursa Efek Indonesia berada dalam bentuk setengah kuat (semi-strong form).

\section{Pembahasan Hasil Pengujian Hipotesis 2}

Berdasarkan hasil uji-t tersebut, p-value (one tailed) sebesar 0,160 lebih besar daripada tingkat signifikansi a sebesar 0,05, sehingga H0 diterima. Hasil tersebut menunjukkan bahwa tidak terdapat peningkatan harga saham yang signifikan sebelum dan sesudah stock split pada perusahaan tidak bertumbuh.

Terdapat peningkatan harga saham yang tidak signifikan sebelum dan sesudah stock split pada perusahaan tidak bertumbuh. Hal ini ditunjukkan oleh t hitung dari selisih antara harga saham sebelum dan sesudah stock split pada perusahaan tidak bertumbuh sebesar 1,134. Angka negatif yang dihasilkan dari selisih antara harga saham sebelum dan sesudah stock split pada perusahaan tidak bertumbuh menunjukkan bahwa harga saham sebelum stock split pada perusahaan tidak bertumbuh lebih kecil daripada harga saham sesudah stock split pada perusahaan tidak bertumbuh. Besarnya rata-rata peningkatan harga saham harian sebelum dan sesudah stock split pada perusahaan tidak bertumbuh adalah 4,65488.

Hasil tersebut sejalan dengan hasil penelitian yang dilakukan oleh Hendrawijaya (2009) dalam Dalimunthe, dkk (2015) yang menunjukkan bahwa tidak terdapat perbedaan yang signifikan pada harga saham sebelum dan sesudah stock split. Akan tetapi, penelitian tersebut tidak menjelaskan lebih lanjut apakah terdapat peningkatan yang tidak signifikan atau justru penurunan pada harga saham. Penelitian tersebut juga tidak secara khusus menggunakan perusahaan tidak bertumbuh sebagai sampel penelitiannya.

Pada dasarnya, investor juga memberikan reaksi positif terhadap stock split yang dilakukan oleh perusahaan tidak bertumbuh, tetapi hanya sebagian kecil investor yang melakukannya. Sebagian investor lainnya cenderung tidak memberikan reaksi terhadap stock split yang dilakukan oleh perusahaan tidak bertumbuh. Hal tersebut menunjukkan bahwa tingkat efisiensi Bursa Efek Indonesia berada dalam bentuk setengah kuat (semi-strong form). Meskipun perusahaan tidak bertumbuh melakukan stock split untuk memberikan sinyal mengenai prospek yang baik di masa yang akan datang, harga saham sebelum dan sesudah stock split tidak menunjukkan peningkatan yang signifikan karena harga tersebut juga mencerminkan secara penuh semua informasi yang dipublikasikan, termasuk informasi tingkat pertumbuhan perusahaan yang tercantum dalam laporan keuangan perusahaan. 
Rendahnya tingkat pertumbuhan perusahaan menyebabkan harga saham sebelum dan sesudah stock split pada perusahaan tidak bertumbuh tidak mengalami peningkatan yang signifikan.

Rendahnya peningkatan harga saham sebelum dan sesudah stock split pada perusahaan tidak bertumbuh menunjukkan terjadinya market underreaction terhadap stock split yang dilakukan oleh perusahaan tidak bertumbuh. Investor cenderung mengabaikan informasi mengenai optimisme manajemen terhadap prospek perusahaan di masa yang akan datang yang disinyalkan melalui stock split pada perusahaan bertumbuh, sebaliknya investor justru berpedoman pada informasi lama yang didapatkannya mengenai tingkat pertumbuhan perusahaan yang rendah. Oleh karena itu, sebagian besar investor cenderung tidak bereaksi terhadap stock split yang dilakukan oleh perusahaan tidak bertumbuh.

\section{Pembahasan Hasil Pengujian Hipotesis 3}

Berdasarkan hasil uji-t tersebut, p-value (one tailed) sebesar 0,350 lebih besar daripada tingkat signifikansi a sebesar 0,05, sehingga H0 diterima. Hasil tersebut menunjukkan bahwa tidak terdapat peningkatan volume perdagangan saham yang signifikan sebelum dan sesudah stock split pada perusahaan bertumbuh.

Terdapat peningkatan volume perdagangan saham yang tidak signifikan sebelum dan sesudah stock split pada perusahaan bertumbuh. Hal ini ditunjukkan oleh thitung dari selisih antara volume perdagangan saham sebelum dan sesudah stock split pada perusahaan bertumbuh sebesar -0,414. Angka negatif yang dihasilkan dari selisih antara volume perdagangan saham sebelum dan sesudah stock split pada perusahaan bertumbuh menunjukkan bahwa volume perdagangan saham sebelum stock split pada perusahaan bertumbuh lebih kecil daripada volume perdagangan saham sesudah stock split pada perusahaan bertumbuh. Besarnya rata-rata peningkatan volume perdagangan saham harian sebelum dan sesudah stock split pada perusahaan bertumbuh adalah 0,000108800.

Hasil tersebut sejalan dengan hasil penelitian yang dilakukan oleh Menendez dan Gomez (2003) dan Hendrawijaya (2009) dalam Dalimunthe, dkk (2015) yang menunjukkan bahwa tidak terdapat perbedaan volume perdagangan saham yang signifikan sebelum dan sesudah stock split. Akan tetapi, penelitian tersebut tidak menjelaskan lebih lanjut apakah terdapat peningkatan yang tidak signifikan atau justru penurunan pada volume perdagangan saham. Penelitian tersebut juga tidak secara khusus menggunakan perusahaan bertumbuh sebagai sampel penelitiannya.

Trading range theory menyatakan bahwa harga saham yang terlalu tinggi menyebabkan saham menjadi tidak likuid, sehingga mendorong perusahaan untuk melakukan 
stock split agar dapat meningkatkan likuiditas saham. Akan tetapi, teori tersebut tidak terbukti dalam penelitian ini. Stock split yang dilakukan oleh perusahaan bertumbuh memang meningkatkan volume perdagangan saham, tetapi besarnya peningkatan tersebut masih cukup rendah.

Pada dasarnya, investor memberikan reaksi positif terhadap stock split yang dilakukan oleh perusahaan bertumbuh. Hal tersebut terbukti dari adanya peningkatan volume perdagangan saham sebelum dan sesudah stock split yang dilakukan oleh perusahaan bertumbuh. Akan tetapi, hanya sebagian kecil investor yang memberikan reaksi positif terhadap stock split yang dilakukan oleh perusahaan bertumbuh, sedangkan sebagian besar investor lainnya cenderung tidak memberikan reaksi terhadap stock split yang dilakukan oleh perusahaan bertumbuh.

Rendahnya peningkatan volume perdagangan saham sebelum dan sesudah stock split pada perusahaan bertumbuh menunjukkan terjadinya market underreaction terhadap stock split yang dilakukan oleh perusahaan tersebut. Market underreaction tersebut terjadi karena keterbatasan pengetahuan investor. Investor tidak mengetahui bahwa stock split yang dilakukan oleh perusahaan bertumbuh, merupakan sinyal positif mengenai prospek perusahaan di masa yang akan datang.

\section{Pembahasan Hasil Pengujian Hipotesis 4}

Berdasarkan hasil uji-t tersebut, p-value (one tailed) sebesar 0,1695 lebih besar daripada tingkat signifikansi $\alpha$ sebesar 0,05, sehingga H0 diterima. Hasil tersebut menunjukkan bahwa tidak terdapat peningkatan volume perdagangan saham yang signifikan sebelum dan sesudah stock split pada perusahaan tidak bertumbuh.

Terdapat penurunan volume perdagangan saham sebelum dan sesudah stock split pada perusahaan tidak bertumbuh. Hal ini ditunjukkan oleh t hitung dari selisih antara volume perdagangan saham sebelum dan sesudah stock split pada perusahaan tidak bertumbuh sebesar 1,084. Angka positif yang dihasilkan dari selisih antara volume perdagangan saham sebelum dan sesudah stock split pada perusahaan tidak bertumbuh menunjukkan bahwa volume perdagangan saham sebelum stock split pada perusahaan tidak bertumbuh lebih besar daripada volume perdagangan saham sesudah stock split pada perusahaan tidak bertumbuh. Besarnya rata-rata penurunan volume perdagangan saham harian sebelum dan sesudah stock split pada perusahaan tidak bertumbuh adalah 0,000418200.

Hasil ini mendukung hasil penelitian Copeland (1979) dalam Jogiyanto (2016) yang menunjukkan bahwa terjadi penurunan likuiditas saham sesudah stock split. Hasil tersebut 
juga sejalan dengan hasil penelitian yang dilakukan oleh Sakti dan Rini (2013) dan Dalimunthe, dkk (2015) yang menunjukkan bahwa tidak terdapat perbedaan volume perdagangan saham yang signifikan sebelum dan sesudah pengumuman stock split pada perusahaan tidak bertumbuh. Akan tetapi, penelitian tersebut tidak menjelaskan lebih lanjut apakah terdapat peningkatan yang tidak signifikan atau justru penurunan pada volume perdagangan saham.

Trading range theory menyatakan bahwa harga saham yang terlalu tinggi menyebabkan saham menjadi tidak likuid, sehingga mendorong perusahaan untuk melakukan stock split agar dapat meningkatkan likuiditas saham. Akan tetapi, teori tersebut tidak terbukti dalam penelitian ini. Stock split yang dilakukan oleh perusahaan ridak bertumbuh justru menimbulkan penurunan volume perdagangan saham.

Penurunan volume perdagangan saham sebelum dan sesudah stock split pada perusahaan tidak bertumbuh menunjukkan terjadinya market underreaction terhadap stock split yang dilakukan oleh perusahaan tidak bertumbuh. Investor cenderung mengabaikan informasi mengenai optimisme manajemen terhadap prospek perusahaan di masa yang akan datang yang disinyalkan melalui stock split pada perusahaan tidak bertumbuh, sebaliknya investor justru berpedoman pada informasi lama yang didapatkannya mengenai tingkat pertumbuhan perusahaan yang rendah. Rendahnya tingkat pertumbuhan perusahaan menyebabkan sebagian investor bereaksi negatif terhadap stock split yang dilakukan oleh perusahaan tidak bertumbuh. Investor menganggap bahwa stock split merupakan sinyal pesimisme perusahaan dalam mengatasi rendahnya likuiditas saham.

\section{Pembahasan Hasil Pengujian Hipotesis 5}

Berdasarkan hasil uji-t tersebut, p-value (one tailed) sebesar 0,0155 lebih kecil daripada tingkat signifikansi $\alpha$ sebesar 0,05, sehingga H0 ditolak dan Ha diterima. Hasil tersebut menunjukkan bahwa terdapat peningkatan abnormal return saham yang signifikan sebelum dan sesudah stock split pada perusahaan bertumbuh. Besarnya rata-rata peningkatan abnormal return saham harian sebelum dan sesudah stock split pada perusahaan bertumbuh adalah 0,014306200 .

Hasil tersebut sejalan dengan hasil penelitian yang dilakukan oleh Dalimunthe, dkk (2015) yang menunjukkan bahwa terdapat perbedaan abnormal return sebelum dan sesudah stock split pada perusahaan bertumbuh.

Peningkatan abnormal return yang signifikan sebelum dan sesudah stock split pada perusahaan bertumbuh menunjukkan adanya reaksi positif yang diberikan oleh investor 
terhadap stock split yang dilakukan oleh perusahaan bertumbuh. Sebagian besar investor tertarik untuk membeli saham yang sudah dipecah oleh perusahaan bertumbuh. Tingginya aktivitas pembelian suatu saham di pasar menyebabkan naiknya harga saham tersebut. Hal tersebut menyebabkan actual return dan abnormal return sebelum dan sesudah stock split mengalami peningkatan yang signifikan.

Berdasarkan signalling theory, peningkatan abnormal return saham sebelum dan sesudah stock split pada perusahaan bertumbuh disebabkan oleh reaksi positif yang diberikan oleh investor terhadap informasi dan optimisme manajemen perusahaan mengenai prospek perusahaan di masa yang akan datang yang disinyalkan melalui stock split. Semakin tinggi tingkat pertumbuhan suatu perusahaan, maka semakin tinggi pula return dan harapan investor terhadap return dan prospek dari perusahaan tersebut di masa yang akan datang. Oleh karena itu, investor tertarik membeli saham sesudah stock split pada perusahaan bertumbuh.

Peningkatan abnormal return saham sebelum dan sesudah stock split yang dilakukan oleh perusahaan bertumbuh menunjukkan bahwa harga saham di Bursa Efek Indonesia mencerminkan secara cepat dan akurat semua informasi yang dipublikasikan, termasuk informasi stock split yang dilakukan oleh perusahaan bertumbuh. Hal ini menunjukkan bahwa tingkat efisiensi Bursa Efek Indonesia berada dalam bentuk setengah kuat (semi-strong form). Abnormal return yang terjadi sebelum dan sesudah stock split di pasar yang efisien berbentuk setengah kuat (semi-strong form) hanya bisa dimanfaatkan dalam jangka pendek.

\section{Pembahasan Hasil Pengujian Hipotesis 6}

Berdasarkan hasil uji-t tersebut, p-value (one tailed) sebesar 0,297 lebih besar daripada tingkat signifikansi a sebesar 0,05, sehingga H0 diterima. Hasil tersebut menunjukkan bahwa tidak terdapat peningkatan abnormal return saham yang signifikan sebelum dan sesudah stock split pada perusahaan tidak bertumbuh.

Terdapat penurunan abnormal return saham sebelum dan sesudah stock split pada perusahaan tidak bertumbuh. Hal ini ditunjukkan oleh t hitung dari selisih antara abnormal return saham sebelum dan sesudah stock split pada perusahaan tidak bertumbuh sebesar 0,579. Angka positif yang dihasilkan dari selisih antara abnormal return saham sebelum dan sesudah stock split pada perusahaan tidak bertumbuh menunjukkan bahwa abnormal return saham sebelum stock split pada perusahaan tidak bertumbuh lebih besar daripada abnormal returnsaham sesudah stock split pada perusahaan tidak bertumbuh. Besarnya rata-rata penurunan abnormal return saham harian sebelum dan sesudah stock split pada perusahaan tidak bertumbuh adalah 0,011253800. 
Hasil penelitian yang dilakukan oleh Sari (2011) menunjukkan bahwa terdapat perbedaan yang signifikan pada abnormal return sebelum dan sesudah stock split, tetapi cenderung ke arah yang negatif. Hasil tersebut sejalan dengan hasil penelitian yang dilakukan oleh Sadikin (2011) dan Irmayani dan Wiagustini (2015) yang menunjukkan bahwa tidak terdapat perbedaan abnormal return saham yang signifikan sebelum dan sesudah stock split. Akan tetapi, penelitian tersebut tidak menjelaskan lebih lanjut apakah terdapat peningkatan yang tidak signifikan atau justru penurunan pada abnomal return. Penelitian tersebut juga tidak secara khusus menggunakan perusahaan tidak bertumbuh sebagai sampel penelitiannya.

Investor memberikan reaksi negatif terhadap stock split yang dilakukan oleh perusahaan tidak bertumbuh. Hal tersebut terbukti dari adanya penurunan abnormal return sebelum dan sesudah stock split pada perusahaan bertumbuh, bahkan abnormal return saham sesudah stock split pada perusahaan tidak bertumbuh bernilai negatif. Penurunan abnormal return saham sebelum dan sesudah stock split pada perusahaan tidak bertumbuh menunjukkan terjadinya market underreaction terhadap stock split yang dilakukan oleh perusahaan tidak bertumbuh. Investor cenderung mengabaikan informasi mengenai optimisme manajemen terhadap prospek perusahaan di masa yang akan datang yang disinyalkan melalui stock split pada perusahaan tidak bertumbuh, sebaliknya investor justru berpedoman pada informasi lama yang didapatkannya mengenai tingkat pertumbuhan perusahaan yang rendah. Rendahnya tingkat pertumbuhan perusahaan menyebabkan sebagian investor cenderung bereaksi negatif terhadap stock split yang dilakukan oleh perusahaan tidak bertumbuh. Investor menganggap bahwa stock split merupakan sinyal pesimisme perusahaan dalam mengatasi rendahnya likuiditas saham.

Signalling theory tidak berlaku bagi stock split yang dilakukan oleh perusahaan tidak bertumbuh. Pada kenyataannya, sebagian besar investor tidak percaya bahwa stock split yang dilakukan oleh perusahaan tidak bertumbuh merupakan sinyal yang diberikan oleh manajemen mengenai prospek perusahaan yang lebih baik di masa yang akan datang, sehingga investor tersebut tidak tertarik untuk membeli saham tersebut sesudah stock split. Hal tersebut terbukti dari adanya penurunan abnormal return saham sebelum dan sesudah stock split pada perusahaan tidak bertumbuh.

Sebagian besar investor tidak bereaksi positif terhadap informasi stock split pada perusahaan tidak bertumbuh yang diumumkan dan dipublikasikan di pasar. Hal tersebut menunjukkan bahwa tingkat efisiensi Bursa Efek Indonesia berada dalam bentuk setengah kuat (semi-strong form). Meskipun perusahaan tidak bertumbuh melakukan stock split untuk memberikan sinyal mengenai prospek yang baik di masa yang akan datang, abnormal 
returnsaham sebelum dan sesudah stock split mengalami penurunan karena harga saham tersebut juga mencerminkan secara penuh semua informasi yang dipublikasikan, termasuk informasi tingkat pertumbuhan perusahaan yang tercantum dalam laporan keuangan perusahaan. Rendahnya tingkat pertumbuhan perusahaan menyebabkan investor tidak membeli saham yang sudah dipecah pada perusahaan tidak bertumbuh. Hal tersebut mengakibatkan harga saham, actual return dan abnormal return sebelum dan sesudah stock split pada perusahaan tidak bertumbuh justru mengalami penurunan. Investor menganggap bahwa stock split merupakan sinyal pesimisme perusahaan dalam mengatasi rendahnya likuiditas saham.

\section{Pembahasan Hasil Pengujian Hipotesis 7}

Berdasarkan hasil uji-t tersebut, p-value (one tailed) sebesar 0,000 lebih kecil daripada tingkat signifikansi $\alpha$ sebesar 0,05, sehingga H0 ditolak dan Ha diterima. Hasil tersebut menunjukkan bahwa harga saham sesudah stock split pada perusahaan bertumbuh lebih besar secara signifikan daripada perusahaan tidak bertumbuh. Besarnya selisih antara rata-rata harga saham sesudah stock split pada perusahaan tidak bertumbuh dan bertumbuh adalah 3396,99244.

Hasil tersebut sejalan dengan hasil penelitian yang dilakukan oleh Dalimunthe dkk (2015) yang menunjukkan bahwa terdapat perbedaan harga saham yang signifikan antara perusahaan bertumbuh dan tidak bertumbuh. Akan tetapi, penelitian tersebut tidak menjelaskan lebih lanjut bahwa perbedaan yang dimaksud adalah harga saham sesudah stock split pada perusahaan bertumbuh yang lebih besar daripada perusahaan tidak bertumbuh.

Hasil tersebut menunjukkan bahwa tingkat pertumbuhan suatu perusahaan akan mempengaruhi harga saham suatu perusahaan, termasuk harga saham sesudah stock split. Dengan kata lain, tingkat pertumbuhan suatu perusahaan akan mempengaruhi reaksi yang diberikan oleh investor terhadap stock split yang dilakukan oleh perusahaan. Semakin tinggi tingkat pertumbuhan suatu perusahaan, maka semakin tinggi pula prospek dan return dari perusahaan tersebut, sehingga semakin baik pula reaksi yang diberikan oleh investor kepada stock split yang dilakukan oleh perusahaan tersebut. Tingginya tingkat pertumbuhan suatu perusahaan akan menarik investor untuk membeli saham pada perusahaan tersebut, terutama saham sesudah stock split dengan nilai nominal yang lebih rendah dan dapat dijangkau oleh investor tersebut. Oleh karena itu, harga saham sesudah stock split pada perusahaan bertumbuh lebih besar daripada harga saham sesudah stock split pada perusahaan tidak bertumbuh. 


\section{Pembahasan Hasil Pengujian Hipotesis 8}

Berdasarkan hasil uji-t tersebut, p-value (one tailed) sebesar 0,038 lebih kecil daripada tingkat signifikansi $\alpha$ sebesar 0,05, sehingga H0 ditolak dan Ha diterima. Hasil tersebut menunjukkan bahwa volume perdagangan saham sesudah stock split pada perusahaan bertumbuh lebih besar secara signifikan daripada perusahaan tidak bertumbuh. Besarnya selisih antara rata-rata volume perdagangan saham sesudah stock split pada perusahaan tidak bertumbuh dan bertumbuh adalah 0,000465800.

Hasil tersebut sejalan dengan hasil penelitian yang dilakukan oleh Sakti dan Rini (2013) dan Dalimunthe dkk (2015) yang menunjukkan bahwa terdapat perbedaan trading volume activity yang signifikan antara perusahan bertumbuh dan tidak bertumbuh. Akan tetapi, penelitian tersebut tidak menjelaskan bahwa perbedaan yang dimaksud adalah trading volume activity sesudah stock split pada perusahaan bertumbuh yang lebih besar daripada perusahaan tidak bertumbuh.

Hasil tersebut menunjukkan bahwa tingkat pertumbuhan suatu perusahaan akan mempengaruhi volume perdagangan saham suatu perusahaan, termasuk volume perdagangan saham sesudah stock split. Dengan kata lain, tingkat pertumbuhan suatu perusahaan akan mempengaruhi reaksi yang diberikan oleh investor terhadap stock split yang dilakukan oleh perusahaan. Semakin tinggi tingkat pertumbuhan suatu perusahaan, maka semakin tinggi pula prospek dan return dari perusahaan tersebut, sehingga semakin baik pula reaksi yang diberikan oleh investor kepada stock split yang dilakukan oleh perusahaan tersebut. Tingginya tingkat pertumbuhan suatu perusahaan akan menarik investor untuk membeli saham pada perusahaan tersebut, terutama saham sesudah stock split dengan nilai nominal yang lebih rendah dan dapat dijangkau oleh investor tersebut. Oleh karena itu, volume perdagangan saham sesudah stock split pada perusahaan bertumbuh lebih besar daripada volume perdagangan saham sesudah stock split pada perusahaan tidak bertumbuh.

\section{Pembahasan Hasil Pengujian Hipotesis 9}

Berdasarkan hasil uji-t tersebut, p-value (one tailed) sebesar 0,0335 lebih kecil daripada tingkat signifikansi $\alpha$ sebesar 0,05, sehingga $\mathrm{H} 0$ ditolak dan Ha diterima. Hasil tersebut menunjukkan bahwa abnormal return saham sesudah stock split pada perusahaan bertumbuh lebih besar secara signifikan daripada perusahaan tidak bertumbuh. Besarnya selisih antara rata-rata abnormal return saham sesudah stock split pada perusahaan tidak bertumbuh dan bertumbuh adalah 0,020686800. 
Hasil tersebut menunjukkan bahwa tingkat pertumbuhan suatu perusahaan akan mempengaruhi abnormal return saham suatu perusahaan, termasuk abnormal return saham sesudah stock split. Dengan kata lain, tingkat pertumbuhan suatu perusahaan akan mempengaruhi reaksi yang diberikan oleh investor terhadap stock split yang dilakukan oleh perusahaan. Semakin tinggi tingkat pertumbuhan suatu perusahaan, maka semakin tinggi pula prospek dan return dari perusahaan tersebut, sehingga semakin baik pula reaksi yang diberikan oleh investor kepada stock split yang dilakukan oleh perusahaan tersebut. Tingginya tingkat pertumbuhan suatu perusahaan akan menarik investor untuk membeli saham pada perusahaan tersebut, terutama saham sesudah stock split dengan nilai nominal yang lebih rendah dan dapat dijangkau oleh investor tersebut. Oleh karena itu, harga, actual return dan abnormal return saham sesudah stock split pada perusahaan bertumbuh lebih besar daripada harga, actual return dan abnormal return saham sesudah stock split pada perusahaan tidak bertumbuh.

\section{KESIMPULAN DAN SARAN}

\section{Kesimpulan}

Berdasarkan hasil penelitian yang telah diuraikan sebelumnya, dapat disimpulkan bahwa terjadi peningkatan harga dan abnormal return saham yang signifikan sebelum dan sesudah stock split pada perusahaan bertumbuh, tetapi tidak terjadi peningkatan volume perdagangan saham yang signifikan sebelum dan sesudah stock split pada perusahaan bertumbuh. Hal tersebut menunjukkan bahwa pada dasarnya investor memberikan reaksi yang positif terhadap stock split yang dilakukan oleh perusahaan bertumbuh, tetapi reaksi positif yang signifikan hanya tercermin pada variabel harga dan abnormal return.

Hasil penelitian juga menunjukkan bahwa tidak terjadi peningkatan harga yang signifikan sebelum dan sesudah stock split pada perusahaan tidak bertumbuh, tetapi justru terjadi penurunan volume perdagangan saham dan abnormal return saham sebelum dan sesudah stock split pada perusahaan tidak bertumbuh. Hal tersebut menunjukkan bahwa pada dasarnya investor cenderung tidak memberikan reaksi yang positif terhadap stock split yang dilakukan oleh perusahaan tidak bertumbuh, bahkan investor cenderung bereaksi negatif terhadap stock split yang dilakukan oleh perusahaan tidak bertumbuh.

Hasil penelitian juga menunjukkan bahwa harga, volume perdagangan saham dan abnormal return saham sesudah stock split pada perusahaan bertumbuh lebih besar secara signifikan daripada harga, volume perdagangan saham dan abnormal return saham sesudah stock split pada perusahaan tidak bertumbuh. Hal tersebut menunjukkan bahwa investor 
memberikan reaksi yang lebih baik terhadap stock split yang dilakukan oleh perusahaan bertumbuh daripada stock split yang dilakukan oleh perusahaan tidak bertumbuh.

\section{Saran}

Berdasarkan hasil penelitian dan kesimpulan yang telah diuraikan sebelumnya, perusahaan bertumbuh hendaknya melakukan stock split dengan tujuan untuk meningkatkan harga saham dan abnormal return saham. Perusahaan hendaknya tidak melakukan stock split untuk meningkatkan volume perdagangan saham karena stock split terbukti tidak dapat meningkatkan volume perdagangan saham secara signifikan. Perusahaan tidak bertumbuh hendaknya tidak melakukan stock split karena stock split yang dilakukan oleh perusahaan tidak betumbuh terbukti tidak dapat meningkatkan harga saham secara signifikan, tetapi justru menurunkan volume perdagangan saham dan abnormal return saham.

Investor hendaknya memperhatikan tingkat pertumbuhan perusahaan terlebih dahulu sebelum memutuskan untuk membeli saham suatu perusahaan. Investor diharapkan membeli saham sebelum stock split pada perusahaan bertumbuh, kemudian segera menjual saham tersebut sesudah stock split karena terbukti menghasilkan abnormal return yang positif dalam jangka pendek. Investor diharapkan tidak membeli saham sebelum stock split pada perusahaan tidak bertumbuh untuk segera menjualnya sesudah stock split karena terbukti menghasilkan abnormal return yang negatif dalam jangka pendek.

Peneliti selanjutnya diharapkan dapat menambah jumlah sampel, khususnya sampel perusahaan tidak bertumbuh. Peneliti selanjutnya juga diharapkan dapat membagi sampel penelitian berdasarkan karakteristik lainnya selain tingkat pertumbuhan, menambah variabel lain yang digunakan sebagai objek penelitian, menggunakan model pengukuran lain dalam penghitungan abnormal return saham, menguji adanya reaksi jangka panjang yang diberikan oleh investor terhadap stock split. Selain itu, peneliti selanjutnya juga diharapkan dapat menambahkan data primer yang bersumber dari wawancara dengan manajemen perusahaan dan investor terkait alasan perusahaan dalam melakukan stock split dan alasan investor dalam membeli saham sebelum dan sesudah stock split.

\section{DAFTAR PUSTAKA}

Astuti, D.W. 2015. Dampak Stock Split terhadap Likuiditas Saham. Skripsi. Program Studi Manajemen Universitas Negeri Yogyakarta. Yogyakarta.

Brigham, E.F. dan L.C. Gapenski. 1994. Financial Management Theory and Practice. The Drydeen Press. Orlando. 
Copeland, T.E. 1979. Liquidity Changes Following Stock Splits. The Journal of Finance. $34(1)$.

Dalimunthe. T.M., Zulbahridar dan V. Diyanto. 2015. Analisis Pengaruh Stock Split terhadap Harga Saham, Volume Perdagangan dan Abnormal Return pada Perusahaan Bertumbuh dan Tidak Bertumbuh. Jom FEKON. 2(2).

Damayanti, N.L., A.T. Atmadja dan N.A.S. Darmawan. 2014. Analisis Pengaruh Pemecahan Saham (Stock Split) terhadap Tigkat Keuntungan (Return) Saham dan Likuiditas Saham: Studi pada Perusahaan yang Go Public di Bursa Efek Indonesia Periode 20082013. E-Journal S1 Ak Universitas Pendidikan Ganesha. 2(1).

De Bond, W. dan R. Thaler. 1985. Does the Stock Market Overreact. Jounal of Finance. 40: 793-808.

Fahmi, I. 2012. Manajemen Investasi: Teori dan Soal Tanya Jawab. Salemba Empat. Jakarta.

Handriani, E. 2015. Investment Opportunity Set (IOS) Berbasis Pertumbuhan Perusahaan dan Kaitannya dengan Upaya Peningkatan Nilai Perusahaan. Jurnal Ekonomi dan Bisnis. 28(1).

Hendrawijaya, M. 2009. Analisis Perbandingan Harga Saham, Volume Perdagangan Saham dan Abnormal Return Saham Sebelum dan Sesudah Pemecahan Saham. Tesis. Program Pasca Sarjana Manajemen Universitas Diponegoro. Semarang

Husnan, S.2010. Dasar-Dasar Teori Portofollio dan Analisis Sekuritas. Edisi 5. UPP STIM YKPN.Yogyakarta.

Irmayani, N.W.D. dan N.L.P. Wiagustini. 2015. Dampak Stock Split terhadap Reaksi Pasar pada Perusahaan yang Terdaftar di Bursa Efek Indonesia. E-Jurnal Manajemen Unud. 4(10): 3287-3316.

Jogiyanto, H.M. 2016. Teori Portofolio dan Analisis Investasi. Edisi Kesepuluh. BPFE Yogyakarta. Yogyakarta.

Jones, C.P., S. Utama, B. Frensidy, I.A, Ekaputra, R.U. Budiman. 2009. Invetments Analysis and Management: An Indonesian Adaptation. Salemba Empat. Jakarta.

Kementerian Keuangan Republik Indonesia. 1990. Keputusan Menteri Keuangan Nomor 1548/KMK.013/1990 tentang Pasar Modal. Kementerian Keuangan RI. Jakarta.

Leung, T.Y. 2005. Do Stock Split Really Signal. Hal. 1-33.

Marwata. 2000. Kinerja Keuangan, Harga Saham dan Pemecahan Saham. Jurnal Riset Akuntansi Indonesia. 4(2): 151-164.

Menendez, S. dan S.Gomez. 2003. Stock Splits: Motivation and Valuation Effect in the Spanish Market. Investigaciones Economics. 27(3): 459-490. 
Ningrum, K.I. 2011. Analisis pengaruh Investment Opportunity Set (IOS) terhadap Return Saham Perusahaan: Studi pada Perusahaan yang Terdaftar di Bursa Efek Indonesia Tahun 2005-2009. Skripsi. Program Studi Manajemen Universitas Sebelas Maret. Surakarta.

Noerfuad, Z.M. 2015. Analisis Pengaruh Stock Split terhadap Harga Saham, Trading Volume Activity dan Return Saham Perusahaa yang Terdaftar di Bursa Efek Indonesia pada Periode 2011-2013. Skripsi. Program Studi Manajemen Universitas Mohammad Husni Thamrin. Jakarta.

Norpratiwi, A.M.V. 2007. Analisis Korelasi Investment Opportunity Set terhadap Return Saham pada Saat Pelaporan Keuangan Perusahaan. Jurnal Akuntansi dan Manajemen. 28(1): 9-22.

Octavio, D.Q. dan I.W.N. Lantara. 2014. Market Overreaction, Size Effect atau Liquidity Effect: Studi pada Bursa Efek Indonesia. Jurnal Manajemen Strategi Bisnis dan Kewirausahaan. 8(1): 11-17.

Sadikin, A. 2011. Analisis Abnormal Return Saham dan Volume Perdagangan Saham Sebelum dan Sesudah Peristiwa Pemechan Saham: Studi pada Perusahaan yang Go Public pada Bursa Efek Indonesia. Jurnal Manajemen dan Akuntansi. 12(1).

Sakti, P.O. dan I. Rini. 2013. Analisis Pengaruh Stock Split terhadap Abnormal Return dan Volume Perdagangan Saham pada Perusahaan Bertumbuh dan Tidak Bertumbuh. Diponegoro Journal of Management. 2(3): 1-13.

Sari, A.B. 2011. Pengaruh Stock Split terhadap Abnormal Return dan Trading Volume Activity pada Perusahaan yang Terdaftar di Bursa Efek Indonesia. Skripsi. Program Studi Manajemen Universitas Negeri Semarang. Semarang.

Van Horne, J.C. dan J.M. Wachowicz. 2012. Fundamentals of Financial Management. 12th Ed. Prentice-hall. New Jersey.

Wijanarko, I. 2012. Analisis Pengaruh Pemecahan Saham (Stock Split) terhadap Likuiditas Saham dan Return Saham. Skripsi. Program Studi Manajemen Universitas Diponegoro. Semarang.

Yi, L.S., S.C. Young, T.H. Kun, dan W.Y. En. 2016. Investor Psychological Traits Overreaction and Underreaction in Malaysian Stock Market. Undergraduate Research Project. Department of Finance Universiti Tunku Abdul Rahman. Perak.

http://www.idx.co.id

http://www.ksei.co.id

http://www.yahoo.finance.com 